\title{
GHAPTER TWENTY-NINE
}

\section{LONGUS}

\author{
J.R. Morgan
}

The handling of time in Daphnis and Chloe is radically different from that of the two 'pre-sophistic' novels by Chariton and Xenophon of Ephesus. The relation of story to fabula is more complex, and the presentation of the story admits the effective use of anachronies. Furthermore, the passage of time, precisely notated, is important in the structure of the novel, and indeed coheres with important themes of the text.

The text is introduced by an account of how the narrator discovered a painting in a grove in Lesbos, sought an explanation of it from a local exegete, and produced his narrative as a verbal counterpart to the visual image. The narration is thus subsequent but reasonably close to the discovery of the painting, but there are no clues as to the dramatic date of the frame narrative. The - strictly speaking, secondary - narrative ${ }^{1}$ it introduces is located in an indeterminate and distant past. Again there are no specific indications of dramatic date, but the action implies a Lesbos of independent city-states, and there are hints that the relations between the two most important of them, Mytilene and Methymna, are intended to reflect Thucydides' narrative of the Mytilenaean revolt of 428 BCE. ${ }^{2}$

The prologue includes not only the narrator's narrative of his encounter with the painting and the composition of the very text we are reading, but also an announcement that his text will be

a possession to delight all mankind, which will heal the sick and comfort the distressed, stir the memory of those who have been in love, and give preparatory instruction to those who have not.

(proem 3)

If we take the text as a whole, then, the end-point of the fabula is each and every act of reading, reaching forward into eternity. ${ }^{3}$ Within this

\footnotetext{
${ }^{1}$ Cf. $S A G N$ r:507.

2 J.R. Morgan 2004: 186; and, with reservations, Cueva 2004: 44-6r.

3 The proem stresses not only the universality of the book's lessons, but their permanent relevance, 'so long as beauty exists and eyes can see' (proem 4).
} 
'primary' fabula, there is a large expanse of unnarrated time, possibly several centuries, covering the period between the end of the story of Daphnis and Chloe and the narrator's encounter with the image of their experiences, and an even longer one, currently running at nearly two millennia and daily increasing, between the composition of the text and the effects on future narratees.

If we only consider the (secondary) narrative introduced by this prologue, we observe that the order of the story displays changes in comparison to its fabula (which we might call the 'secondary' fabula). The story begins with the discovery and adoption of the baby Daphnis by the goatherd Lamon, followed at an interval of two years, by a symmetrical account of the discovery and adoption of the infant Chloe by the shepherd Dryas. The exposure of the two children by their natural families is presented only through two external completing actorial analepses after their recognition in the final book of the novel. Daphnis' father, Dionysophanes, narrates the circumstances of his son's exposure in 4.24.I-2, and Chloe's father Megacles has a symmetrical counterpart at $4 \cdot 35 \cdot 3-4$. The story thus withholds the truth of the children's origins and identities and makes them the object of the primary narratee's curiosity and speculation, until the earlier part of the fabula is dramatically revealed at the resolution of the plot.

The starting point of the fabula, however, predates the birth and exposure of its protagonists. The important secondary character, the cowherd Philetas, in an internal completing actorial analepsis, tells Daphnis and Chloe of the epiphany of the god Eros in his garden. In the course of this account, he reports the god's own external completing actorial analepsis:

'I know in your first youth you used to graze your wide herd of cattle on that hill-side; I was with you there as you played your pipes beside those oak-trees when you were in love with Amaryllis, but you could not see me, even though I was standing right next to the girl. I made her yours, and now you have fine sons, herdsmen and farmers.'

$(2.5 \cdot 3)$

A few sentences later, Philetas himself tells Daphnis and Chloe of the same events, from a different perspective:

'I was once young myself, and in love with Amaryllis. I lost my appetite, never drank a drop or slept a wink. My soul ached, my heart throbbed, my body was a-cold. I would cry out as though I was being beaten, fall silent as though I was a dead man, dive into rivers as though I was on fire. I would call on Pan to aid me, for he had been in love himself with 
Pitys. I would bless Echo for repeating Amaryllis' name after me. I would smash my pipes, because they charmed my cows but did not bring me Amaryllis.' ${ }^{4}$

$(2.7 \cdot 4-6)$

These analepses establish an analogy between the experiences of Daphnis and Chloe and those of an earlier generation, which allows them to identify their own 'illness' as love. They also underwrite the novel's gospel of the never-ending cycles of nature and human life.

Similarly, although the story ends with the wedding-night of Daphnis and Chloe, the narrator inserts an external prolepsis into the penultimate chapter, which extends the fabula to include the rest of Daphnis and Chloe's lives and the birth of their own children:

Not only that day but for as long as they lived, they led a pastoral life for most of the time. The gods they worshipped were the Nymphs, Pan and Love; they owned very many flocks of sheep and goats, and thought that fruit and milk were the sweetest food. Moreover, they put a baby boy to a nanny-goat, and set their second-born, a little daughter, to suck at the dugs of a ewe. The former they named Philopoemen, the latter Agele, and in this way of life these children grew old with them. ${ }^{5} \quad(4 \cdot 39 \cdot \mathrm{I}-2)$

The 'secondary' fabula thus stretches from the youth of Philetas to the old age of Philopoemen and Agele, comprising three turns of the cycle of life in demonstration of the point that the experience of love recurs in each successive generation. The 'primary' fabula extends this truth into an infinite future.

The period between the youth of Philetas and the birth of Daphnis and Chloe is not narrated. The entire lifetime of the two protagonists, however, is. After their discovery by their foster-fathers, thirteen years are covered in a single sentence (I.7.I). The prolepsis at the end, as we have seen, covers the rest of their lives after marriage. Between these two comes the main story, carefully arranged into a series of seven seasons, and thus covering a period of a little less than two years. The seasons articulate the progression of the protagonists' love. ${ }^{6}$ In the first spring (I.9-1.22) Daphnis and Chloe fall in love; their passion becomes more heated in the summer (1.23-27). Autumn is a particularly important season: each of the two autumns in the sequence commands an entire book. The first (1.28-3.2) includes the meeting with Phile-

${ }^{4}$ Note the iterative presentation of most of this passage.

${ }^{5}$ The last clause of the passage quoted is excised by some editors, but its implication that Daphnis and Chloe lived to an extreme old age is important.

${ }^{6}$ J.R. Morgan I994: 66-69. 
tas, who gives Daphnis and Chloe their first instruction about Eros. The succeeding winter $\left(3 \cdot 3^{-\mathrm{II}}\right)$ is a period of suspension and separation; but in the second spring (3.12-23) amorous feelings are reactivated and heightened and Daphnis is initiated into sex by his neighbour Lycaenion. The second summer sees the first mention of marriage. The second autumn comprises the whole of the fourth book, and brings about the recognition of the protagonists and culminates in their marriage. It is clear that the seasonal cycle counterpoints the erotic development of Daphnis and Chloe. There is a double ideological point to this deployment of temporal markers. Firstly, it demonstrates the close connection between humanity and nature; and secondly the cycle of the natural year mirrors the cycle of human generations, whose thematic importance we have already seen emphasised by the forward and backward extension of the fabula beyond the limits of the story.

Longus' awareness and exploitation of time is also to be seen within each of the seasons. Typically each of the seasons begins with a description of the countryside and its activities. The general state of the protagonists is conveyed through iterative narration, detailing their typical actions over the whole season. Within the season a few days are singled out for extensive singulative treatment, and on those days the narrator seems to take particular care to plant markers of the passage of time. The best way to illustrate this rather individual narrative pattern will be to analyse one or two of the seasons in some detail.

The first spring begins with a temporal pause ${ }^{7}$ as the narrator describes the vernal flora and fauna. This glides into an iterative account of the young couple's response:

Everything was so full of the joy of spring that they, being young and innocent, copied what they heard and saw. Hearing the birds singing, they sang; seeing the lambs skipping, they leaped lightly, and copying the bees they gathered the flowers; some they tucked inside their clothes, some they wove into daisy chains and brought to the Nymphs. As they grazed their flocks side by side they did everything together. Many a time [pollakis] did Daphnis round up sheep that strayed off, and many a time [pollakis] did Chloe drive down over-bold goats away from the cliffs.

${ }^{7}$ Unlike Chariton $(\rightarrow$ ) and Xenophon of Ephesus $(\rightarrow)$, Longus does have a number of passages where time is paused or which stand outside narrative time entirely, as for instance the excursus on the swimming of cows at I.30.6, or the description of the Lesbian coastline, in the present tense, at 2.12.2. The best example of a pause is the lengthy ekphrasis of Dionysophanes' park at $4 \cdot{ }^{2-3} 3$. 
There were even times when one looked after both flocks while the other was engrossed in a game. Their games were pastoral and childish. She would find some asphodel stalks somewhere, start weaving a cricket-trap, and forget all about her sheep as she toiled away at it. He would cut some slender reeds, bore through the partitions at the joints, stick them together with soft wax, and practise playing the pipes till night fell.

(I.9.2-I0.2)

Explicit markers, such as the word pollakis, and the use of the imperfect tense indicate that these are repeated actions without precise temporal location. The narrative becomes singulative and specific for the first signs of love; the tense of the narrative switches to the aorist. The day in question starts at I.I2.I, when two of Daphnis' goats get into a fight and he falls into a pit while chasing them. He is extracted by Chloe, assisted by a cowherd from a nearby farm, and goes to wash in the spring by the shrine of the Nymphs. It is the sight of his naked body that causes Chloe to feel sexual attraction for the first time. The day ends at I.I3.3, when they drive their flocks home. The next day (I.I3.4) Chloe watches Daphnis closely, as her feelings grow more intense. She persuades him to take another bath. At this point the narrative briefly drops back into iterative mode, describing her symptoms of love over the ensuing days, in the imperfect tense (I.13.5-6). A singular occasion is marked by the word pote ('one day') and the reappearance of aorist verbs: this day functions as a scene, with a lengthy soliloquy by Chloe.

The next chapter (I.I5) begins with a narratorial analepsis, containing the information that Dorcon, the cowherd who had helped to pull Daphnis out of the hole, had fancied Chloe from that day forth. He starts bringing gifts, at first to both, but then exclusively to Chloe; all this is iterative, and it is not clear exactly how it relates temporally to the foregoing narrative. It makes most sense to suppose that the giving of gifts began before the day of Chloe's soliloquy and continues after it. Within the days of gift-giving, one is briefly singled out (pote and the aorist) as particularly significant: this is when Dorcon presents Chloe with a kissubion, an ivy-cup, the programmatic artefact of pastoral poetry; here the shift in frequency marks the symbolic importance of the moment. Another specific occasion $(p o t e)^{8}$ begins at I.I5.4. Daph-

8 There is no indication, explicit or implicit, of the period separating this occasion from the previous specific day. The logic of the narrative requires the passage of several but not many days. 
nis and Dorcon have an argument about who is the more handsome. The rhythm slows to a full-blown scene as their speeches are given in full. The kiss which Daphnis wins as the prize is the beginning of his erotic awakening. Just as Chloe's first feelings led to an iterative passage in which the symptoms of love were repeatedly enacted, so Daphnis now is reduced to a symmetrically iterative aporia (I.I7.2-4). He too has a soliloquy, but his differs from Chloe's in that it is presented as iterative:

If ever he was alone and apart from her, he would break into this sort of absurd soliloquy. ${ }^{9}$

The next section is more summary, but clearly concerns a single occasion. Dorcon approaches Chloe's foster-father Dryas, and asks for her hand in marriage, only to be rebuffed (I.I9.I-3). Dorcon devises a rustic trick to get his hands on Chloe, and its execution takes place in the next scene (I.20.2-22.4). ${ }^{10}$ The time of day is established by the fact that Chloe is bringing the flocks to the spring to drink: this element of the pastoral routine has been carefully located by the narrator as taking place after the midday siesta (I.8.2). Dorcon lies in wait and jumps on her, only to find himself beset by her dogs. After he is rescued and helped on his way by the innocent protagonists, they spend the rest of the day collecting the animals that had scattered in terror. Thus ends the day, but the next day (I.22.4) their unnamed feelings are as strong as ever.

Within the overall scheme of this season, it is clear enough that certain days are marked out by their singularity as of particular importance: the two days when Chloe and Daphnis respectively experience their first twinges of desire, the day of the kissubion (ivy-cup), the day of Dorcon's attempted rape. These are either cardinal points of the plot or of iconic significance. This use of rhythm and frequency to articulate and emphasise key points of the story is a recurrent feature of the text. For example, in the ensuing summer, which covers a much shorter span of text than the spring, the single incident treated in this way is the famous episode of the swallow and cicada, which encodes, in a symbolic way, some of Longus' primary themes and truths. ${ }^{11}$

\footnotetext{
9 Imperfect tense, apelèrei.

10 Again the intervening period is not specified.

11 J.R. Morgan 2004: I70-I7ı. And again in the novel's only winter, the season's only action is encompassed in two consecutive days.
} 
The first autumn displays a similar pattern. The day of Daphnis and Chloe's encounter with Philetas, who tells them about Eros, is emphasised by its expansive treatment (2.3.I-8.I). The longest section of narrative in this season, however, concerns the disruption of the countryside by a party of young city people from Methymna. This begins with an iterative narration of their journey along the coast, in which typical holiday activities are presented as repeated actions (2.12.I-5). We slip into a single day, and the aorist tense, at 2.I3.I, when a rustic steals their mooring-rope. The next morning (heōthen, 2.13.2), the Methymnaeans discover the loss and then sail on to Daphnis and Chloe's area. By a freakish accident, their ship is set adrift when one of Daphnis' goats gnaws through its temporary mooring. They first resort to violence and then a quasi-judicial hearing, which ends in them being chased away. They apparently get back to Methymna by land on the same day, and convene an assembly which votes for war with Mytilene. A military expedition is launched on the following day (tês epiousēs, 2.20.I), during which Chloe is abducted, and Daphnis has a vision of the Nymphs, promising her return. By the time he completes his devotions, it is nearly sunset (2.24.3). The ensuing night is narrated twice (repeating narration): once briefly from Daphnis' standpoint (2.24.4), and then again at greater length from the perspective of the Methymnaeans $(2.25 \cdot \mathrm{I}-4)$. It is filled with supernatural horrors. The next day begins at 2.26.I: the terrors continue, until at midday the Methymnaean commander experiences a vision of the god Pan. Chloe is released and is reunited with Daphnis 'around the time of the second pasture' (2.30.I), that is to say, late in the afternoon, after the flocks have rested through the hottest part of the day. There are sacrifices and rustic celebrations, until this eventful day comes to an end with nightfall at 2.31.2. The next day celebrations continue, with exchanges of stories and dancing, and Daphnis and Chloe make their way home when it is already dark (2.38.I). The following day is another of those iconic ones, completing the second book with Daphnis and Chloe taking competitive oaths by different deities, an important moment in the story's agenda of gender differentiation.

This stretch of narrative is thus spread over six consecutive days: (I) 2.I3.I; (2) 2.I3.2-I9.3; (3) 2.20.I-25.4; (4) 2.26.I-3I.2; (5) 2.3I.2-38.2; (6) 2.38.2-6. It is obvious that the four central days are allocated more story-time (and hence text) than the first and the last in the sequence, reflecting the density of incident and its thematic importance. It is also striking that the narrator has been generous with temporal markers 
within this sequence, even if some of them have a rustic flavour. The passage of time, and the length of time represented by the successive incidents of the plot is clearly significant to him. A similar precision can be found, for example, in the elaborate intrigues and resolutions of the final book.

One particular temporal indicator acquires symbolic importance in this novel: noon. In Daphnis and Chloe this is a numinous time, when the action of the divine is at its most felt. It is at the very height of midday (mesembrias akmazousess) that Lamon discovers the infant Daphnis (I.2.2). Later midday prompts scenes of heightened eroticism between the two, as yet innocent, protagonists: first when the sight of one another's bodies bewitches them (I.24.I), and later as the setting for the episode of the swallow and cicada (I.25.I). It is at noon that Eros appears to Philetas in his garden (2.4.I) and Pan appears to the Methymnaean general in a supernaturally induced sleep (2.26.5).

\section{Analepses}

This novel completely lacks narratorial repeating analepses of the sort that occur in Chariton $(\rightarrow)$. Narratorial completing analepses are fairly few and minor in extent, if not always in importance. On three occasions they are internal, as we have seen in the case of Dorcon's infatuation with Chloe. ${ }^{12}$ The second example concerns Daphnis and Chloe's piety to the Nymphs:

Even before that time they had never passed by without a thought: every day at the beginning of grazing they would stop at the shrine, and on their way home from grazing they would kneel in worship, and they never failed to make some offering, a flower or a fruit or fresh foliage or a libation of milk. ${ }^{13}$

$(2.2 .5)$

The third is the introduction of the important secondary character Lycaenion, and here the analepsis is both internal and external, containing information both about her earlier life and her recent interest in Daphnis:

This man had a little lady he had brought from the city, young, pretty and by country standards rather glamorous. Her name was Lycaenion.

12 I.I5.I: 'Dorcon ... had been amorously inclined towards Chloe since that day, and with every day that passed the flames in his heart burned fiercer'.

13 Note the iterative narration. 
Every day she watched Daphnis drive his goats out to pasture in the morning and home from pasture in the evening, and she had set her heart on making him her lover, using presents as a bait to catch him; on one occasion she had even waylaid him when he was by himself and given him a set of pipes as a gift and honey in the comb, and a deerskin bag. ${ }^{14}$

$(3 \cdot \mathrm{I} 5 \cdot \mathrm{I}-3)$

The other external narratorial analepsis is also connected with the introduction of a new secondary character. When Daphnis' natural brother Astylus first appears, we are told that he was 'not unacquainted with the pain of love' (4.I7.I).

Of the actorial analepses, we have already noted the external completing ones in which the two natural fathers, Dionysophanes and Megacles, reveal the circumstances of their children's exposure as babies. There are one or two cases of internal completing actorial analepsis, the most extensive and important of which is Philetas' account of his encounter with the god Eros, which (as noted above) contains within it external analepses about Philetas' youth. Two other actorial analepses are interestingly placed in the mouth of the divine Nymphs, thus supplementing the usual proleptic function of divine utterance with an authoritative revelation of the past. In the first of these analepses the Nymphs reveal to Daphnis that they have been protecting Chloe from her birth (2.23.I); in the second they reveal what happened to the Methymnaean ship after it was set adrift by Daphnis' goat (3.27.2). This analepsis is coupled with a divine prolepsis, in that they are able to guide Daphnis to the purse of money that was lost with the vessel and that will enable him to become a viable suitor of Chloe, and to look beyond that, in coded terms, to his recognition as a member of the urban aristocracy. ${ }^{15}$

The majority of actorial analepses are repeating ones, and have the simple argument function of transferring necessary information from one character to another. ${ }^{16}$ The most extensive of them occurs when Chloe is reunited with Daphnis after her Methymnaean adventure:

${ }^{14}$ Here too the analepsis for a large part takes the form of iterative narration.

15 'In time to come you really will be rich' (3.27.5).

16 This forms an illuminating contrast with the summary analepses of which Xenophon of Ephesus $(\rightarrow)$ is so fond: in that case argument function is less important than reminding the primary narratee of the complexities of the plot. Longus' text, with a higher level of literary ambition, assumes a primary narratee who can concentrate on and retain the story. 
She told the whole story: the goats' ivy, the sheeps' howling, the pine budding on her head, the fire on the land and the noise on the sea, the two kinds of piping, one martial, one peaceful, the night of terror, and how when she did not know the way the music had shown her the way home.

$(2.30 .3)$

The unusual degree of detail here allows Daphnis to recognise the supernatural nature of her deliverance and thus to identify the agency of Pan, which had been foretold in his vision of the Nymphs.

Other extended analepses cluster around the recognitions of Daphnis and Chloe. The symmetrical completing external analepses of the two natural fathers are prompted by symmetrical repeating internal analepses from the two foster-fathers, in which they disclose their discovery of the exposed infants (4.19.4-5, 30.3-4). These are good examples of the care the narrative takes to motivate its incidents. Lamon, for example, is worried by the threat that Daphnis will be taken away to the city to become the plaything of the homosexual parasite Gnathon; he tries to avert this by producing the tokens that prove to his master Dionysophanes that Daphnis is of a wealthy family, only for the master to recognise the tokens as the ones exposed with his own child.

Most of the other actorial analepses are simple, but an interesting variant is the partial analepsis where a character deliberately and significantly suppresses one element of the narrative. In the first book, Daphnis is briefly abducted by pirates, who also beat up Dorcon and steal his cows. He is rescued when, in return for a kiss, the dying Dorcon gives Chloe a set of pipes to which the cows have been trained to respond, resulting in the capsizing of the pirate ship. Here is what happens when Daphnis and Chloe are reunited:

She told him the whole story: how she had run to Dorcon, how he had trained the cows, how she had been told to play the pipes, and that Dorcon was dead. The kiss was the only thing she did not mention, out of modesty.

Daphnis never does learn about that kiss, but symmetrically he conceals from Chloe his erotic tuition in the wood by Lycaenion.

\section{Prolepses}

The prolepses in Longus fall into the following categories: a) narratorial prolepses; b) divine prolepsis, principally by the means of dreams; c) actorial prolepses; d) seeds; e) intertextual prolepsis; f) a series of myths 
told by characters, which apart from their 'argument' function act as coded prolepses for the primary narratee ('key' function).

a) We have already mentioned the narratorial prolepsis at the end of the novel, which extends the fabula to include the birth of the protagonists' children. Other narratorial prolepses are few in number and limited in extent. When Daphnis and Chloe make pious offerings to the Nymphs, the narrator comments:

Later they were repaid for this by the gods. ${ }^{17}$

This is not typical of this narrator, however. Elsewhere his proleptic interventions are restricted to anticipation of the immediately ensuing event: so when Daphnis is looking for the putrefying dolphin which conceals the Methymnaeans purse, the narrator says 'he was not to have much difficulty finding it'. ${ }^{18}$

This is the most convenient place to discuss the complex temporal function of the painting described by the primary narrator in the prologue. At the very end of the text, we discover that the image was dedicated by Daphnis and Chloe themselves, and that it functions thus, for them, as a pictorial narrative of their experiences. ${ }^{19}$ For the primary narratee, on the other hand, the images of the picture functions in the same way as, for example, the proems of the Homeric $(\rightarrow)$ epics: they announce events of the story he is about to read: ${ }^{20}$

It showed women giving birth and others dressing the babies in swaddling clothes, babes abandoned and beasts of the flock feeding them, shepherds taking them up and young people making pledges, a pirate raid and an enemy invasion, and much else, all of it amorous. (proem 2)

In listing these images, the narrator re-enacts his own earlier failure to understand them until explained by an exegete. The painting is conceived as containing several panels in which the same characters recur, rather like a comic strip, but the narrator at this stage affects not to see the connections between them. He also presents them in an order which does not exactly reflect that of the story, in which the pirate

\footnotetext{
17 This concludes the iterative analepsis about their previous piety. The interplay of past and future is made explicit in the Greek: ton proteron khronon ... husteron.

18 3.28.2; compare I.II.4, where the single word hōde ('in the following manner') guides the narratee into the next chapter.

${ }^{19}$ For the identification of the images dedicated by Daphnis and Chloe with the painting seen by the narrator see Wouters 1989-1990.

${ }^{20}$ It is better not to speak of prolepsis in this case, since the story has not started yet.
} 
raid precedes the protagonists' exchange of oaths. ${ }^{21}$ All this is of course deeply duplicitous: at the moment of narration the narrator is already in possession of all relevant information. The result is that the primary narratee is also unable to reconstruct the story from this scant data: he is provided with a few individual episodes from the plot, but no sense of the narrative grammar that binds them together. The pictorial 'proem' whets rather than blunts his curiosity.

b) Longus' narrator does not have privileged access to knowledge of the gods' intentions. The gods do, however, issue instructions to characters through dreams. At 1.7.2 Lamon and Dryas have simultaneous dreams of Eros, whom they do not recognise, commanding them to send their foster-children out to the pastures. This is balanced by dreams at the end of the story, when Eros appears to the two natural fathers. For Dionysophanes he unstrings his bow (so indicating the accomplishment of his mission) and gives the command to produce Chloe's tokens at a feast. When he does so, the tokens are recognised by Megacles, who announces that he has had a dream that he is about to become a father. ${ }^{22}$ The Nymphs appear twice to Daphnis. In the first they reveal their lifelong care for Chloe, and then foretell her safe return from the clutches of the Methymnaeans through the agency of Pan (2.23.3-5). The second vision is when they guide him to the lost purse, and look forward to a time when he will be really wealthy $\left(3 \cdot 27 \cdot 4^{-5}\right)$. Pan appears to Bryaxis, the Methymnaean commander, and commands him to return Chloe; he also drops the remark that she is a girl 'from whom love intends to make a story', an intensely metanarrative moment looking forward to the production of the novel itself (2.27.2). ${ }^{23}$

The gods thus employ non-enigmatic dreams to give the characters orders that will bring about their will. For the primary narratee, however, the dreams indicate the benevolent control that the gods, particularly Eros - whose agents Pan and the Nymphs are-, exert over the whole of the protagonists' lives. Their proleptic function thus extends beyond the specific injunction to guarantee that the ending of the whole story will be a happy and meaningful one.

${ }^{21}$ For fuller discussion see J.R. Morgan 2004: I45-I48, and the bibliography given there.

22 Megacles thus gives an analeptic account of a proleptic dream; but the prolepsis is merely of the revelation of something that has already occurred. The same device is found in Homer $(\rightarrow)$ and Heliodorus $(\rightarrow)$.

${ }^{23}$ Discussed more fully by J.R. Morgan 2004: 193 . 
c) As in other novels, the characters of Daphnis and Chloe speculate about and plan for the future. It seems to be a feature of this text, however, that such actorial prolepses are often erroneous, and thus creative of irony. A simple example comes when Chloe has been abducted by the Methymnaeans, and Daphnis looks forward pessimistically to her future life (2.22.2). The primary narratee's sense of generic propriety will surely suggest that the story will not short-circuit at this point and in this way. I want to single out two particular examples of actorial analepsis, which seem to be of particular thematic significance.

The first concerns the suggestion that the protagonists' foster-families have material ambitions dependent on their foundlings eventually being reunited with their biological families, whose wealth is guaranteed by the recognition tokens. So, early on, Dryas refuses Dorcon's suit for Chloe,

reflecting that the girl was worthy of a better match than this, and fearing that he would get into serious trouble if he were ever found out. (I.19.3)

This motif resurfaces at the end of the third book, when at first Dryas is tempted by the gifts offered by Chloe's suitors, but then reflects

that the maiden was of too high a class for agricultural suitors and that if she ever found her real parents she would make him and his wife very wealthy.

Symmetrically Lamon is hostile to the suggestion of marriage between Chloe and Daphnis,

who in his recognition tokens gave signs of high estate, and who would make them free and masters of a larger farm.

These ambitions generate the interplay of characters between the two foster-fathers, each of whom plays his cards close to his chest and cunningly exploit the situation to maximum financial and social advantage.

The second comes when Lycaenion has initiated Daphnis into sexual intercourse, and looks forward to the time when he will try out his new found skills on Chloe:

'When Chloe does this sort of wrestling with you, she will scream and cry and lie in a pool of blood. Don't be scared of the blood, but when you persuade her to give herself to you, bring her to this spot, so that no one can hear her if she shouts, and if she bleeds she can wash in the stream. ${ }^{24}$

$(3 \cdot 19 \cdot 2-3)$

${ }^{24}$ Fuller discussion in J.R. Morgan 2004: 208-210. 
Every aspect of her vision of the future is significantly wrong. Chloe eventually loses her virginity, joyfully and apparently without pain or mess, on her wedding night. More to the point, Lycaenion is wrong to assume that Daphnis will immediately have sex with Chloe. His new knowledge has brought with itself the existential freedom not to use it immediately or unreflectively, as well as an awareness of the responsibilities that belong with love. Lycaenion's false prolepsis marks the difference between her facile and physical view of sexual relations and the romantic ethos that surrounds the protagonists and which the novel ultimately underwrites.

d) The seed par excellence is the recognition token. When the two babies are discovered at the very beginning of the novel, each is accompanied by valuable objects. The mere existence of these objects creates the presumption that the children will be recognised and that the tokens will have a part to play in the process. As we have seen, attention is drawn to them - and to their function-on several occasions during the course of the novel. The recognition scenes of which they are the seeds duly take place and constitute the resolution of the plot.

e) The seed-function of the recognition tokens is partly intertextual. Stories of children exposed at birth and eventually recognised by and reunited with their natural families were widespread in ancient literature, but are particularly characteristic of the plots of New Comedy. The intertextual relation to New Comedy is accentuated in the last book, where stereotypical characters from the comic stage, such as the feckless young man and the parasite, signal the shift of the plot from countryside to city. Recognition of the intertextual switch from Theocritean pastoral to Menandrian comedy brings with it the realisation that the plot will resolve in a comic manner, as in fact it does, with recognition paving the way to a wedding celebration typical of comic endings.

There is, however, one intertextual prolepsis which is characteristic of Longus' procedures, and quite distinct from this sort of general awareness of generic proprieties. At the end of the third book comes an episode where Daphnis exerts his newly acquired manhood by climbing a tree, against Chloe's wishes, to fetch her a beautiful apple which had been left on the topmost branch by the fruit-pickers. Verbal echoes confirm that this is modelled on a famous poem by Sappho, one of Longus' principal intertexts, and especially appropriate for a story set 
on Lesbos. The image of the apple left on the topmost bough is from a wedding song or epithalamium, also imitated by Catullus. An ancient commentator explains that the apple represents the bride, whose virginity remains unpicked for her husband..$^{25}$ The primary narratee was thus cued to understand the apple episode as a prolepsis of the projected wedding; deterred by Lycaenion's warnings from taking Chloe's virginity literally, Daphnis does so figuratively.

f) Finally, a brief word about the three inset myths in each of the first three books: the myth of the wood-dove as told by Daphnis to Chloe, and containing a reference to the story of Pan and Pitys (I.27); the myth of Pan and Syrinx as told by Lamon after the recovery of Chloe from the Methymnaeans (2.34); and the myth of Pan and Echo, again told to Chloe by Daphnis, in explanation of an actual echo (3.23). It is widely recognised that these myths stand in some sort of counterpoint to the novel's central plot. Details from each of them can be read as proleptic in a narrow sense. Thus the theft of cows in the first myth immediately precedes the pirate-raid in which Dorcon's cows are stolen, and the dismemberment of Echo in the third myth is aligned with the painful and bloody defloration which Lycaenion has envisaged for Chloe. As a series, the myths present an escalation both of male violence towards a female victim and of overt sexuality. The later clearly reflects the growing sexual awareness of Daphnis and Chloe, while the latter points towards Daphnis' eventual taking of Chloe's virginity. In each of the myths, the female victim undergoes a metamorphosis that results in the creation of new beauty and harmony. This, in one sense, points towards the metamorphosis of Chloe from girl to woman, from virgin to bride, and beyond that to her transformation into text. The relation between these myths and the main story is not a straightforwardly proleptic one, however. Daphnis is not to be equated with Pan, and his romantic love avoids the infliction of suffering which is a recurrent feature of the three myths. Rather, the myths rehearse narrative possibilities that the main stories avoids. ${ }^{26}$

${ }^{25}$ Sappho fr. I05 LP, also used in Cat. 62. The explanation of the symbol is by Himerius (Or. 9.I6). Discussion, and further bibliography, in J.R. Morgan 2004: 22I222.

${ }^{26}$ For fuller discussion of these myths see J.R. Morgan 2004: I7I-I72, I95-198, 213216; also MacQueen 1985; Philippides I980-I98I; Pandiri 1985; Wouters I991. 


\section{Conclusion}

Longus' handling of time is one aspect of a new level of sophistication, both technical and ethical, that demarcates Daphnis and Chloe from Chariton and Xenophon of Ephesus. His novel is compact and Alexandrian in its aesthetics. 